\title{
Relationship between embryo recovery rate and uterine lavage fluid composition in postpartum mares
}

\author{
Tiina ReILAs ${ }^{\mathrm{a}}$, Mirja Huhtinen ${ }^{\mathrm{a}}$, Mari OKSANEN ${ }^{\mathrm{b}}$, Terttu Katila ${ }^{\mathrm{b} *}$

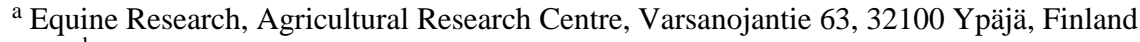 \\ b Department of Clinical Veterinary Sciences, Faculty of Veterinary Medicine, \\ University of Helsinki, Pohjoinen pikatie 800, 04920 Saarentaus, Finland
}

(Received 20 May 1999; accepted 4 July 2000)

\begin{abstract}
The aim of the study was to determine whether neutrophil numbers (PMN), trypsininhibitor capacity (TIC), lysozyme, $\mathrm{N}$-acetyl- $\beta$-D-glucosaminidase (NAGase), $\beta$-glucuronidase (B-Gase), total protein, and plasmin in uterine lavage fluid of postpartum (p.p.) mares, either at the time of foal heat insemination or around the time of arrival of the embryo in the uterus, could be used in predicting conception. Fifteen mares were inseminated within $13 \mathrm{~h}$ after the first p.p. ovulation. Uterine lavage fluids were successfully collected from 9 out of 12 mares before insemination and from all 15 mares before embryo recovery 7 to 8 days after insemination. The embryo recovery rate was $53 \%(8 / 15)$. Prior to insemination, PMN, TIC and lysozyme levels were elevated in 3/4 mares not producing embryos. However, only 1/5, 1/5 and 0/5 mares producing embryos had elevated levels of PMN, TIC, and lysozyme, respectively. None of the parameters was significantly different in mares with or without embryos, but lysozyme was the closest to significance $(p=0.07)$. In both groups of mares, activities of NAGase $(p<0.01)$ and B-Gase $(p<0.05)$ were significantly higher in dioestrus than immediately after ovulation. At embryo recovery, NAGase was higher in mares not producing embryos $(p<0.05)$. The results suggest that a long-lasting inflammation is the best explanation for low pregnancy rates during the first p.p. oestrus. Further research is needed to establish whether lysozyme, or possibly TIC, could be used in predicting conception at foal heat.
\end{abstract}

mare / foal heat / uterine fluid / inflammation / embryo recovery

Résumé - Relations entre le taux de récupération des embryons et la composition du liquide de lavage de l'utérus chez la jument lors du post-partum. Le taux de récupération des embryons a été relié à la composition du fluide utérin chez 15 juments qui ont été inséminées dans les $13 \mathrm{~h}$ suivant la première ovulation post-partum. Les liquides de lavage ont été récupérés avant l'insémination chez 9 juments sur 12 et chez 15 sur 15 avant la collecte des embryons 7 à 8 jours après. Les mesures ont porté sur le nombre des neutrophiles, les teneurs en plasmine et en protéines totales, la concentration en lysozyme, l'activité de l'inhibiteur de la trypsine (TIC), les activités de la N-acétylD-glucosaminidase (N-Gase), et de la $\beta$-glucoronidase (B-Gase). Le taux de récupération des

* Correspondence and reprints

E-mail: terttu.katila@ saari.vetmed.helsinki.fi 
embryons a été de $53 \%(8 / 15)$. Avant insémination, les paramètres mesurés n'ont pas été significativement différents entre les juments avec ou sans embryon. Cependant le nombre des neutrophiles, l'activité TIC et les taux de lysozymes ont été élevés chez 3 des 4 juments qui n'ont pas produit d'embryons mais seulement chez $1 / 5,1 / 5$ et $0 / 5$ respectivement chez celles qui en ont eu. Dans les deux groupes de jument (avec ou sans embryon), les activités de la N-Gase $(p<0,01)$ et de la B-Gase $(p<0,05)$ ont été plus élevées au moment de la collecte qu'à l'insémination. Au moment de la collecte, l'activité de la N-Gase a été plus élevée chez les juments sans embryons $(p<0,05)$. Ces résultats suggèrent qu'une inflammation prolongée de l'utérus est reliée aux faibles taux de gestation obtenus lors du premier œstrus post-partum. Des recherches complémentaires sont nécessaires pour établir si le lysozyme ou éventuellement l'activité de l'inhibiteur de la trypsine sont utilisables pour prédire le succès de la conception à ce moment.

jument / oestrus / liquide utérin / inflammation / récupération d'embryon

\section{INTRODUCTION}

Over the past several decades, it has been reported that pregnancy rates of mares bred in the first postpartum (p.p.) oestrus are lower than those of mares bred in subsequent heats: 37 vs. $58 \%$ [5], 49 vs. $66 \%$ [31], 52 vs. 66\% [6]. Recently, however, much higher foal heat pregnancy rates have been reported: $72 \%$ [4] and $82 \%$ [1]. Management factors such as better feeding, adequate exercise, improved hygiene, use of ultrasonography, and more advanced veterinary skills in artificial insemination, oestrus and ovulation control presumably contribute to the improved results. Low foal heat pregnancy rates have been explained by decreased conception rates or by increased embryonic death rates before pregnancy examination $[6,23]$. Because embryo recovery rates from foaling mares inseminated in p.p. oestrus are lower than in nonlactating mares ( $48 \%$ vs. $71 \%$ ) [8], it seems likely that either decreased conception rates or increased embryonic death rates in the oviduct is the reason for low foal heat pregnancy rates.

Intrauterine fluid (IUF) aspirated or absorbed into tampons from mares with ultrasonically visible fluid accumulations have been shown to decrease spermatozoal motility in vitro $[26,29]$. It seems that IUF quality as estimated by ultrasonography at the time of insemination has a great influence on fertility. Embryo recovery rates from mares exhibiting echogenic IUF are significantly reduced as compared to mares with no fluid (14 vs. 90\%) [29], but small amounts of anechogenic IUF do not affect embryo recovery rates (67 vs. 65\%) [26]. Foaling mares having ultrasonically detectable IUF in the first p.p. oestrus do not conceive as well as mares with no fluid (33 vs. 84\%) [22]. Fluid accumulation may indicate an inflammatory process. However, bacteria or leukocytes in uterine swabs obtained during foal heat had no correlation with pregnancy rates $[7,11]$ or with embryo recovery rates [8].

The biochemistry of endometrial secretions during the first p.p. oestrus is of great interest because spermatozoa are exposed to this environment on their way to the oviduct. There are, however, relatively few studies concerning the composition of p.p. uterine fluids. One study revealed that total protein and $\mathrm{IgG}$ concentrations, and acid phosphatase activities in uterine lavage fluids are higher in p.p. mares than in cyclic mares [15]. In our preliminary study [14], total protein concentration, proteolytic activity in the form of plasmin, antiproteolytic activity in the form of trypsin-inhibitor capacity (TIC) and lysosomal enzymes such 
as N-acetyl- $\beta$-D-glucosaminidase (NAGase), $\beta$-glucuronidase (B-Gase), acid phosphatase and lysozyme were shown to peak around day 4 p.p. and to decline rapidly thereafter. After day 16, protein and enzyme levels in uterine lavage fluid of p.p. mares decreased to normal levels, indicating that the secretory function of the endometrium had presumably been restored to its pregravid state [25]. Some of the parameters such as lysozyme, plasmin, and TIC have been reported to be elevated in uterine lavage fluid in association with uterine inflammation, whereas acid phosphatase, B-Gase, and NAGase accumulate in the uterine lumen in response to progesterone [27].

It has been determined that breeding during foal heat does not impair pregnancy rates in subsequent heats [17], but in some instances it may be advantageous to breed only mares which have good chances of conception, for example with the use of frozen semen, imported fresh semen, or embryo transfers. The purpose of this study was to examine the relationship between embryo recovery rate and the composition of uterine fluid by comparison of uterine lavage fluids collected after the first p.p. ovulation, and before embryo recovery, from both those p.p. mares producing and not producing embryos. High proteolytic and antiproteolytic activities, and lysozyme concentrations, in particular, were hypothesised to have a negative impact on fertilisation and subsequent embryo recovery.

\section{MATERIALS AND METHODS}

\subsection{Animals}

The material consisted of 15 p.p. mares owned by the Equine Research Station. They were of different breeds (weight $450-750 \mathrm{~kg}$ ) and aged from 4 to 16 years (mean 10.3 years). They had foaled 0 to 6 times prior to this experiment, had no history of reproductive failure and were clinically normal. Foalings took place from
February to May. In 12 mares, the placenta were expelled within $3 \mathrm{~h}$ after foaling. Three mares passed their placenta within $8 \mathrm{~h}$ p.p. after being treated with oxytocin (25 IU i.m.). Semen from a Finnhorse stallion of known fertility was used for artificial insemination (AI).

\subsection{Ovulation control and AI}

Rectal palpation and ultrasonography of the ovaries and uterus commenced 5 days after parturition. The examination was repeated every other day until occurrence of a follicle of 35 to $40 \mathrm{~mm}$ in diameter. At this point, ovarian activity was monitored every $12 \mathrm{~h}$ until ovulation was detected. To detect additional ovulations, follow-up of follicles $30 \mathrm{~mm}$ or larger was continued for 2 days after the first ovulation. All mares were inseminated within one hour of detection of ovulation. The insemination dose was $>500 \times 10^{6}$ progressively motile spermatozoa in skim milk-glucose extender. Blood samples were collected for progesterone determination to confirm the physiological status of mares. Serum progesterone was measured by direct radioimmunoassay (Farmos Diagnostica, Turku, Finland).

\subsection{Uterine lavage and embryo recovery}

Collection of uterine lavage fluids was attempted from 12 of 15 mares immediately after ovulation detection but before insemination. Fifty millilitres of Dulbecco phosphate-buffered saline $\left(37^{\circ} \mathrm{C}\right)$ (DPBS; Gibco BRL, Life Technologies, Paisley, Scotland ) was infused into the uterus via a modified 22 G Foley catheter (Bard Ltd, Sunderland, UK) and the uterus was briefly massaged per rectum. After 5 min of equilibration, the lavage fluid was allowed to flow into sterile centrifuge tubes. When required, the recovery of fluid was assisted by manipulation of the uterus via the rectum. Twenty millilitres of each lavage fluid 
was centrifuged at $2000 \mathrm{~g}$ for $15 \mathrm{~min}\left(4^{\circ} \mathrm{C}\right)$. The supernatant was collected and portions were stored at $-20{ }^{\circ} \mathrm{C}$ until analysis.

Seven to eight days after ovulation detection, uterine lavage fluid was collected from all 15 mares, via an embryo flushing catheter (Embryonen-Spühlkatheter Ch 26, Klinika Medical-Vertriebs GmbH, Hannover, Germany), by flushing the uterus with $50 \mathrm{~mL}$ of prewarmed DPBS. After being examined for the presence of embryos, $20 \mathrm{~mL}$ of each lavage fluid was centrifuged, and portions of the supernatant were stored at $-20{ }^{\circ} \mathrm{C}$ until analysis.

After the $50 \mathrm{~mL}$ flush with DPBS, the uteri were flushed 3 times with DPBS (1 000, 2000 and $2000 \mathrm{~mL}, 37^{\circ} \mathrm{C}$, successively) supplemented with $1 \%$ heat-inactivated foetal calf serum (FCS; Gibco BRL, Life Technologies, Paisley, Scotland), 0.1\% glucose, and $25 \mathrm{mg} \cdot \mathrm{L}^{-1}$ kanamycin. The fluid was collected in $1000-\mathrm{mL}$ graduated cylinders and allowed to stand for $20 \mathrm{~min}$. Then, all but $50 \mathrm{~mL}$ of the fluid was siphoned from the top of each cylinder. Retained fluids and rinse fluid from glassware were examined for the presence of embryos using a stereomicroscope. Once an embryo was located, it was transferred to flush medium with $5 \%$ FCS, photographed, classified according to McKinnon \& Squires [21] and measured with a microscope.

\subsection{Bacteriological examination and neutrophil count}

Uterine lavage fluids were plated onto blood agar with a loop. Microbial growth after $48 \mathrm{~h}$ at $37^{\circ} \mathrm{C}$ was scored as none, +1 (1-10 colonies), +2 (11-100 colonies), and +3 (>100 colonies). Bacterial growth was considered significant when more than 10 colonies of potential pathogens ( $\beta$-haemolytic streptococcus, Staphylococcus aureus, haemolytic Escherichia coli, Klebsiella pneumoniae, Pseudomonas aeruginosa) were recovered per plate.
Identification was based on colony morphology, haemolysis, the catalase test and Gram stain. Eosin methylene blue agar was used when necessary.

Ten millilitres of lavage fluid were centrifuged and the pellet was resuspended in $1 \mathrm{~mL}$ of saline $\left(0.9 \% \mathrm{wt} \cdot \mathrm{vol}^{-1} \mathrm{NaCl}\right)$. Polymorphonuclear neutrophils (PMN) were counted using a haemocytometer. PMN counts were considered indicative of inflammation when more than $1 \times 10^{4} \mathrm{PMN} \cdot \mathrm{mL}^{-1}$ were recovered from the lavage fluid.

\subsection{Biochemical analysis of uterine lavage fluids}

All analyses except lysozyme determinations were performed on microtitration trays as previously described [27]. Protein concentrations were measured with the BioRad Protein Assay (Bio-Rad, Richmond, California, USA). TIC was measured by means of a colorimetric assay, as described by Mattila et al. [19]. The detection limit of the assay was 0.1 . The intra- and inter-assay coefficient of variation (CV) was $6 \%$. Plasmin activity was determined with a fluorogenic coumaryl substrate [18]. The sensitivity of the assay, when translated to enzyme activity. $\mathrm{min}^{-1}$, was about $0.03 \mu \mathrm{mol}$ product $\cdot \mathrm{min}^{-1} \cdot \mathrm{L}^{-1}$. The intra-assay $\mathrm{CV}$ was about $2 \%$, the inter-assay $\mathrm{CV}$ was not determined. NAGase was analysed by the fluorogenic method of Linko-Löppönen and Mäkinen [16] using 4-methyl-umbelliferyl$\mathrm{N}$-acetyl- $\beta$-D-glucosaminide as a substrate. The method for determining B-Gase activity was essentially the same as for NAGase; the substrate was 4-methyl-umbelliferyl$\beta$-glucuronide. The sensitivities of the assays were $0.02 \mu \mathrm{mol}$ product $\cdot \mathrm{min}^{-1} \cdot \mathrm{L}^{-1}$ for NAGase and $0.005 \mu \mathrm{mol}$ product. $\min ^{-1} \cdot \mathrm{L}^{-1}$ for B-Gase. The intra- and interassay CV was $2 \%$ for NAGase and $5 \%$ for B-Gase. A modification of the turbidimetric method described by Mörsky [24] was used to determine lysozyme concentrations [27]. The detection limit of the assay was 
$0.3 \mathrm{mg} \cdot \mathrm{L}^{-1}$. The intra- and inter-assay $\mathrm{CV}$ were about $6 \%$ and $12 \%$, respectively.

\subsection{Statistical analysis}

Statistical analyses were performed with the Statgraphics program [30]. Because of right-skewed distributions and heterogeneity in variances, the values were first transformed logarithmically. The means and variances of protein concentrations, enzyme activities, and neutrophil numbers in uterine lavage fluids were analysed using $t$-tests for paired samples or for two independent samples: a one-sample analysis was used to compare uterine lavage fluids collected within $13 \mathrm{~h}$ after the first p.p. ovulation with those collected 7 to 8 days later, and a twosample analysis to compare uterine lavage fluids from mares producing an embryo with those from mares not producing an embryo. The Mann-Whitney test was used when the assumption of normality was not applicable. Associations between total protein, NAGase, B-Gase and plasmin in uterine lavage fluid collected 7 to 8 days after the first p.p. ovulation were subjected to a Pearson correlation analysis. Significance was set at $p<0.05$. The values in the text are presented as mean \pm SEM.

\section{RESULTS}

The mares ovulated $12.8 \pm 0.6$ days p.p. (range 8 to 18 days). At the time of ovulation detection, nonechogenic intrauterine fluid accumulations of less than $20 \mathrm{~cm}$ in maximum depth were detected by ultrasonography in 2 mares. The average volumes of lavage fluids recovered were $20 \mathrm{~mL}$ (range 0 to $49 \mathrm{~mL}$ ) and $28 \mathrm{~mL}$ (range 18 to $39 \mathrm{~mL}$ ) for immediately and 7 to 8 days after ovulation detection, respectively. In 3 out of 12 mares, recovery of lavage fluid was unsuccessful during the first p.p. oestrus.

Embryo recovery rate was $53 \%(8 / 15)$. No twin embryos were recovered. Five of eight embryos were early blastocysts (150 to $190 \mu \mathrm{m}$ in diameter) and three were expanded blastocysts (400 to $450 \mu \mathrm{m}$ in diameter). All embryos were considered normal and of excellent or good quality.

Immediately after ovulation detection, PMN numbers, TIC, and lysozyme concentrations were elevated in 3/4 nonembryoproducing mares (Tab. I). However, only $1 / 5,1 / 5$ and $0 / 5$ embryo-producing mares had elevated levels of PMN, TIC, and lysozyme, respectively. Two lavage fluids were bacteriologically positive, but the growth was considered insignificant

Table I. PMN numbers, TIC, and lysozyme concentrations in uterine lavage fluids collected after detection of the first p.p. ovulation.

\begin{tabular}{lcccc}
\hline Mare & $\begin{array}{c}\text { PMN } \\
10^{6} \cdot \mathrm{mL}^{-1}\end{array}$ & $\begin{array}{c}\text { TIC } \\
\text { relative units }\end{array}$ & $\begin{array}{c}\text { Lysozyme } \\
\text { Mg.L }\end{array}$ & Embryo* \\
\hline CI & 0.11 & 0.41 & 0.63 & - \\
UN & 0.30 & 1.84 & 0.75 & - \\
IV & 2.98 & 0.67 & 2.16 & - \\
EV & ND & ND & ND & - \\
ME & 0.18 & ND & ND & + \\
CL & ND & 0.44 & ND & + \\
MI & ND & ND & ND & + \\
HT & ND & ND & ND & + \\
KA & ND & ND & ND & + \\
\hline
\end{tabular}

PMN: neutrophils; TIC: trypsin-inhibitor capacity; ND: not detected; *: embryo recovery results 7 to 8 days later. 
( $<10$ colonies or +2 growth of mixed bacteria).

No significant differences were detected amongst 9 postovulatory samples from embryo-producing and nonembryo-producing mares (Tab. II). Both in embryo-producing mares $(n=5)$ and in nonembryoproducing mares $(n=4)$, NAGase and B-Gase activities were significantly lower soon after ovulation than in dioestrus ( $p<0.01$ and $\mathrm{p}<0.05$, respectively), whereas total protein concentrations and plasmin activities did not differ $(p>0.05)$.

At embryo recovery 7 to 8 days after ovulation detection, NAGase activity was lower $(p<0.05)$ in embryo-producing mares than in nonembryo-producing mares (Tab. III). Lysozyme concentration and PMN numbers exceeded the detection limit in one out of 15 samples. TIC was elevated in one slightly bloodstained sample. Total protein concentration correlated positively with NAGase $(r=0.74 ; p<0.05)$ and with B-Gase $(r=0.71 ; p<0.05)$ in embryo-producing mares $(n=8)$. In nonembryo-producing mares $(n=7)$, there was a positive correlation between total protein concentration and NAGase $(r=0.80 ; p<0.05)$, and a negative correlation between B-Gase and plasmin $(r=-0.86 ; p<0.05)$.

Table II. Comparison of protein concentrations, enzyme activities and PMN numbers in uterine lavage fluids collected after detection of the first p.p. ovulation from mares producing or not producing embryos 7 to 8 days later.

\begin{tabular}{lccc}
\hline & $\begin{array}{c}\text { Embryo recovered } \\
(n=5)\end{array}$ & $\begin{array}{c}\text { No embryo recovered } \\
(n=4)\end{array}$ & $P$ value \\
\hline Total protein $\left(\mathrm{g} \cdot \mathrm{L}^{-1}\right)$ & $0.496 \pm 0.036$ & $0.892 \pm 0.305$ & 0.234 \\
TIC (relative units) & $0.10 \pm 0.09$ & $0.73 \pm 0.39$ & 0.097 \\
Plasmin $\left(\mathrm{U} \cdot \mathrm{L}^{-1}\right)$ & $0.058 \pm 0.008$ & $0.104 \pm 0.032$ & 0.305 \\
Lysozyme $\left(\mathrm{mg} \cdot \mathrm{L}^{-1}\right)$ & $\mathrm{ND}$ & $0.89 \pm 0.45$ & 0.069 \\
NAGase $\left(\mathrm{U} \cdot \mathrm{L}^{-1}\right)$ & $2.28 \pm 0.52$ & $2.90 \pm 0.73$ & 0.515 \\
B-Gase $\left(\mathrm{U} \cdot \mathrm{L}^{-1}\right)$ & $0.002 \pm 0.001$ & $0.015 \pm 0.008$ & 0.168 \\
PMN $\left(10^{6} \cdot \mathrm{mL}^{-1}\right)$ & $0.04 \pm 0.04$ & $0.85 \pm 0.71$ & 0.101 \\
\hline
\end{tabular}

Values are expressed as means \pm SEM. TIC: trypsin-inhibitor capacity; NAGase: N-acetyl- $\beta$-D-glucosaminidase; B-Gase: $\beta$-glucuronidase; PMN: neutrophils; U: $\mu$ mol product $\cdot \mathrm{min}^{-1}$; ND: not detected.

Table III. Comparison of protein concentrations and enzyme activities in uterine lavage fluids collected before embryo recovery 7 to 8 days after ovulation detection from mares producing or not producing embryos.

\begin{tabular}{lccc}
\hline & $\begin{array}{c}\text { Embryo recovered } \\
(n=8)\end{array}$ & $\begin{array}{c}\text { No embryo recovered } \\
(n=7)\end{array}$ & $P$ value \\
\hline Total protein $\left(\mathrm{g} \cdot \mathrm{L}^{-1}\right)$ & $0.390 \pm 0.061$ & $0.617 \pm 0.092$ & 0.070 \\
Plasmin $\left(\mathrm{U} \cdot \mathrm{L}^{-1}\right)$ & $0.114 \pm 0.033$ & $0.164 \pm 0.051$ & 0.874 \\
NAGase $\left(\mathrm{U} \cdot \mathrm{L}^{-1}\right)$ & $11.57 \pm 1.60$ & $17.78 \pm 2.05$ & 0.035 \\
B-Gase $\left(\mathrm{U} \cdot \mathrm{L}^{-1}\right)$ & $0.074 \pm 0.033$ & $0.226 \pm 0.114$ & 0.054 \\
\hline
\end{tabular}

Values are expressed as means \pm SEM. NAGase: N-acetyl- $\beta$-D-glucosaminidase; B-Gase: $\beta$-glucuronidase; $\mathrm{U}: \mu \mathrm{mol}$ product $\cdot \mathrm{min}^{-1}$. 


\section{DISCUSSION}

None of the parameters measured at the time of AI were significantly related to the embryo recovery rate 7 days later. The concentration of lysozyme was closest to significance $(p=0.07)$; embryo recovery rates were $0 / 3$ and $5 / 6$ in mares having lysozyme present or not present in the uterine lavage fluid, respectively. Since lysozyme in the uterine fluid correlates well with neutrophil numbers [12, 27], inflammation might not have completely subsided in these mares. Neutrophils in uterine biopsy specimens obtained 5 days p.p. have been shown to correlate significantly with foal heat pregnancy rate [11], whereas neutrophils obtained by uterine swabs did not correlate with foal heat pregnancy rate $[7,11,20]$. In the present study, embryo recovery rates were $1 / 4$ and $4 / 5$ in mares having PMN present or not present in their uterine lavage fluid at the time of AI, respectively. The lavage technique is more sensitive than swabbing in diagnosing endometritis on the basis of quantitative cytological and microbiological findings [3]. Determination of lysozyme concentrations may be an even more sensitive method of quantifying uterine inflammation than neutrophil numbers. Given the small number of mares in the present study, further research is needed to establish whether lysozyme can be used in predicting conception.

TIC was detected in $44 \%$ of the uterine lavage fluids collected immediately after the first p.p. ovulation. In our previous study, TIC peaked around day 6 p.p., declined rapidly thereafter, but still was detectable in all samples collected before the first p.p. ovulation. During foal heat, the highest values of TIC are associated with uterine inflammation [25]. Although embryo recovery was not predicted by TIC $(p<0.10)$, the association was in the expected direction, since embryo recovery rates were $1 / 4$ and $4 / 5$ in mares having TIC present or not present in the uterine lavage fluid, respectively. However, our hypothesis that plasmin activity at the time of insemination would be harmful to sperm, was not supported.

At the time of embryo recovery, NAGase activities in uterine lavage fluid were higher $(p<0.05)$, and B-Gase activities tended to be higher $(p<0.10)$ in mares not producing embryos than in mares producing embryos. Because the serum progesterone levels and the mean interval from ovulation detection to embryo recovery were not significantly different between the two groups of mares, factors other than progesterone seem to have been responsible for higher activities. In mares not producing embryos, B-Gase activity did not correlate with total protein concentration as it did in embryoproducing mares, but instead correlated negatively with plasmin activity. These findings suggest that the composition of uterine fluid in nonembryo-producing mares was different from that in embryo-producing mares.

In many respects, extensive changes take place in the mare's uterus during one week time p.p., particularly during the first week. Changes have been reported in uterine size $[1,7,10,22,28]$, uterine histology [2, 7, 9], elimination of bacteria and inflammation $[7,11,13,20]$, and secretory activity $[14$, 15]. The results of the present study show that the uterine environment changes markedly even after the first p.p. ovulation. Thus, the measuring of uterine fluid parameters at the end of foal heat is probably of no use in predicting the suitability of the uterine environment to embryonic development, but parameters associated with uterine inflammation might predict fertilisation.

\section{CONCLUSION}

The results indicate that a long-lasting inflammation is the best explanation for low pregnancy rates of the first p.p. oestrus. Uterine lavage is an effective method in sampling the mare's uterus due to the large area contacted by the lavage fluid. Despite the 
dilution of native uterine secretions, endometrial inflammation in mares can be detected by analysis of uterine lavage fluid for lysozyme and TIC, as was also shown in our previous studies [25, 27]. Lysozyme and possibly TIC detection in uterine secretions from 5 to 7 days p.p. could be used as a basis for exclusion; only those mares that have cleared their uterus from inflammatory products would be inseminated. These methods of determination are not, however, suitable for routine use in the field. If quick mareside tests could be developed, these analyses could become feasible methods for studfarm practice.

\section{ACKNOWLEDGEMENTS}

The authors thank the personnel at the Department of Pharmacology and Toxicology, Faculty of Veterinary Medicine, University of Helsinki, Finland for technical assistance, advice, and facilities for protein and enzyme analyses.

\section{REFERENCES}

[1] Arrott C., Macpherson M., Blanchard T., Varner D., Thompson J., Simpson B., Bruemmer J., Vogelsang S., Fernandez M., Fleet T., Burns P., Biodegradable estradiol microspheres do not affect uterine involution or characteristics of postpartum estrus in mares, Theriogenology 42 (1994) 371-384.

[2] Bailey J.V., Bristol F.M., Uterine involution in the mare after induced parturition, Am. J. Vet. Res. 44 (1983) 793-797.

[3] Ball B.A., Shin S.J., Patten V.H., Lein D.H., Woods G.L., Use of a low-volume uterine flush for microbiologic and cytologic examination of the mare's endometrium, Theriogenology 29 (1988) 1269-1283.

[4] Camillo F., Marmorini P., Romagnoli S., Vannozzi I., Bagliacca M., Fertility at the first post partum estrous compared with fertility at the following estrous cycles in foaling mare and with fertility in nonfoaling mares, J. Eq. Vet. Sci. 17 (1997) 612-616.

[5] Caslick E.A., The sexual cycle and its relation to ovulation with breeding records of the thoroughbred mare, Cornell Vet. 27 (1937) 187-206.

[6] Fiolka G., Kuller H., Lender S., Embryonale Mortalität beim Pferd (Embryonic mortality in the horse), Mh. Vet.-Med. 40 (1985) 835-838.
[7] Gygax A.P., Ganjam V.K., Kenney R.M., Clinical, microbiological and histological changes associated with uterine involution in the mare, J. Reprod. Fertil. Suppl. 27 (1979) 571-578.

[8] Huhtinen M., Reilas T., Katila T., Recovery rate and quality of embryos from mares inseminated at the first post-partum oestrus, Acta Vet. Scand. 37 (1996) 343-350.

[9] Katila T., Histology of the post partum equine uterus as determined by endometrial biopsies, Acta Vet. Scand. 29 (1988) 173-180.

[10] Katila T., Koskinen E., Oijala M., Evaluation of the post partum mare in relation to foal heat breeding. I. Rectal palpation, vaginoscopy and ultrasound scanning, J. Vet. Med. A 35 (1988) 92-100.

[11] Katila T., Koskinen E., Oijala M., Parviainen $\mathrm{P}$., Evaluation of the post-partum mare in relation to foal heat breeding. II Uterine swabbing and biopsies, J. Vet. Med. A 35 (1988) 331-339.

[12] Katila T., Lock T.F., Hoffmann W.E., Smith A.R., Lysozyme, alkaline phosphatase and neutrophils in uterine secretions of mares with differing resistance to endometritis, Theriogenology 33 (1990) 723-732.

[13] König K., Klinische und bakteriologische Untersuchung des Genitaltraktes der Stute während des Puerperiums, Vergleich der Untersuchungsergebnisse hinsichtlich des Alters und der weiteren Fruchtbarkeit der Stuten sowie Beurteilung der Besamungstauglichkeit der Fohlenrosse aus bakteriologischer Sicht. Inaugural-Dissertation, Hannover, 1975.

[14] Kotilainen T., Kuusela E., Virtanen K., Katila T., Changes in the composition of uterine flushings in post partum mares, J. Reprod. Fertil. Suppl. 44 (1991) 704-705.

[15] LeBlanc M.M., Hansen P.J., Buhi W.C., Uterine protein secretion in postpartum and cyclic mares, Theriogenology 29 (1988) 1303-1316.

[16] Linko-Löppönen S., Mäkinen M., A microtiter plate assay for $\mathrm{N}$-acetyl- $\beta$-D-glucosaminidase using a fluorogenic substrate, Anal. Biochem. 148 (1985) 50-53.

[17] Loy R.G., Characteristics of postpartum reproduction in mares, Vet. Clin. North Am., Large Animal Practice 2 (1980) 345-359.

[18] Mattila T., Sandholm M., Milk Plasmin, N-Acetyl- $\beta$-D-glucosaminidase, and antitrypsin as determinants of bacterial replication rates in whey, J. Dairy Sci. 69 (1986) 670-675.

[19] Mattila T., Saari S., Vartiala H., Sandholm M. Milk antitrypsin as a marker of bovine mastitis correlation with bacteriology, J. Dairy Sci. 68 (1985) 114-122.

[20] McCue P.M., Hughes J.P., The effect of postpartum uterine lavage on foal heat pregnancy rate, Theriogenology 33 (1990) 1121-1129. 
[21] McKinnon A.O., Squires E.L., Morphologic assessment of the equine embryo, J. Am. Vet. Med. Assoc. 192 (1988) 401-406.

[22] McKinnon A.O., Squires E.L., Harrison L.A., Blach E.L., Shideler R.K., Ultrasonographic studies on the reproductive tract of mares after parturition: effect of involution and uterine fluid on pregnancy rates in mares with normal and delayed first postpartum ovulatory cycles, J. Am. Vet. Med. Assoc. 192 (1988) 350-352.

[23] Merkt H., Fohlenrosse und Fruchtresorption, Zuchthygiene 1 (1966) 102-108.

[24] Mörsky P., Turbidimetric determination of lysozyme with Micrococcus lysodeikticus cells: Reexamination of reaction conditions, Anal. Biochem. 128 (1983) 77-85.

[25] Reilas T., Katila T., Proteins and enzymes in uterine lavage fluid of postpartum and nonparturient mares, J. Reprod. Dom. Anim (in press).

[26] Reilas T., Katila T., Mäkelä O., Huhtinen M., Koskinen E., Intrauterine fluid accumulation in oestrous mares, Acta Vet. Scand. 38 (1997) 69-78.
[27] Reilas T., Ristiniemi M., Katila T., Influence of hormone replacement therapy and bacterial inoculation on proteins and enzymes in uterine lavage fluid of ovariectomized mares, J. Reprod. Dom. Anim. 33 (1998) 11-19.

[28] Sertich P.L., Watson E.D., Plasma concentrations of 13,14-dihydro-15-ketoprostaglandin F2alpha in mares during uterine involution, J. Am. Vet. Med. Assoc. 201 (1992) 434-437.

[29] Squires E.L., Barnes C.K., Rowley H.S., McKinnon A.O., Pickett B.W., Shideler R.K., Effect of uterine fluid and volume of extender on fertility, Proc. 35th Ann. Conv. Am. Ass. Equine Practitioners, 1989, pp. 25-30.

[30] STSC, Inc. Statgraphics7 Statistical Graphics System, 2115 East Jefferson Street, Rockville, Maryland, USA, 1986.

[31] Sullivan J.J., Turner P.C., Self L.C., Gutteridge H.B., Bartlett D.E., Survey of reproductive efficiency in the quarter-horse and Thoroughbred, J. Reprod. Fertil. Suppl. 23 (1975) 315-318. 
T. Reilas et al. 